Ann. Génét. Sél anim, 1969, 1 (3), 207-217.

\title{
IDIOGRAMS OF YAK (BOS GRUNNIENS), CATTLE (BOS TAURUS) AND THEIR HYBRID
}

\author{
C.P. POPESCU \\ Department of Genetics, \\ Institute of Zootechnical Researches, 63, Dr Staicovici, Sector 6-Bucarest (Romania) (*)
}

ABSTRACT

The karyotypes of Yak (Bos grunniens L.) and Cattle (Bos taurus L.) are alike both numerically and morphologically. However, idiograms of the two species reveal differences both in autosomes and in sexual chromosomes. The idiogram of hybrids (Bos grunniens L. $\sigma^{*} \times$ Bos taurus L. O) represents roughly an average of parental idiograms.

Numerous authors have studied the chromosomes of some hybrid animals and their parental species for the purpose of explaining the infertility of interspecific hybrids (BASRUR and Moon, I967; LAY and NADLER, I969; MAKINo et al., I963).

The great differences existing between the karyotypes of certain species constitute probably the causes of the infertility of their hybrids (Makino et al., I963).

In Yak karyotype was described by Zuirrs by means of histological methods, as being made up of 62 (ZUITIN, I935) and then of 60 chromosomes (ZUITrN, I938).

In a previous work we described the karyotype in this species by the method of leucocyte culture (DERLOGEA et al., 1967). It is made up of 60 chromosomes, very similar to those of the species Bos taurus. All autosomes are telocentric, while the sexual chromosomes are submetacentric just as in Bos taurus.

Hybrid males resulting from the Bos grunniens of $\times$ Bos taurus $q$ crossing are sterile. Testicle histological sections show the blocking of spermatogenesis at spermatogonia stage (DERLOGEA et al., 1967). Hybrid females are fertile. For a analysis of similarities and dissimilarities of the karyotypes of these two species and of their hybrids, we proposed to draw up the idiogram.

(*) Present adress : Station centrale de Génétique animale, C.N.R.Z., 78 - Jouy-en-Josas. 


\section{I. - MATERIAL AND METHOD}

Investigations were undertaken on two specimens of Bos grunniens (1 male and 1 female) four specimens of Bos taurus (2 females and 2 males) and three hybrids (two females and one male) resulting from the crossing of a male Yak with Bos taurus females.

The method of leucocyte culture after Moorhead's method, modified by Nichols et al. (1962), was worked by.

Cultures were treated with colchicine and then with an hypotonic solution and fixed in a mixture of methyl alcool and acetic acid $(3: 1)$. The slides were air dried and stained with Giemsa stain. The best cells were photographed at immersion (1 500x) on a Kodak microfilefilm. For the idiogram make up chromosomes in 10 Bos grunniens (5 ơ and $\left.5 \delta^{*}\right)$ and 15 hybrid (10 $q \%$ and $5 \sigma^{*} \sigma^{*}$ cells were measured. In Bos taurus, the idiogram was made by measuring 10 cells (5 우 and $\left.5 \delta^{\star}\right)$ selected from 106 analysed cells with very good dispersion, derived from 4 studied specimens ( 2 우 and $2 \delta^{\star} \sigma^{\circ}$ ) and was compared with the Yak idiogram and with that of hybrids.

Each chromatid was measured separately and the mean was computed for each chromosome. The mean between the chromosomes of each pair was then computed so as to obtain the values of the haploid set. Measurements were made on photographs with compasses, on a micrometrical scale with a $0,1 \mathrm{~mm}$ precision. The relative lengths of each chromosome were computed and were expressed as one thousandth parts of the total length of the haploid set. The total length was computed by the formula :

$$
\mathrm{Lt}=\frac{58 \mathrm{~A}+\mathrm{X}}{2} \text { in males and } \mathrm{Lt}=\frac{58 \mathrm{~A}}{2}+\frac{\mathrm{X}+\mathrm{X}}{2} \text { in females. }
$$

The means of the relative length of each chromosome were computed for each sex separately, as well as the means for each species, taking into consideration both sexes, except for sexual chromosomes (table 1). For each chromosome of the haploid set, the variance, the standard deviation and the standard error of the mean were computed.

\section{II. - RESULTS AND DISCUSSION}

The makeup of the idiogram in these species of the genus Bos is difficult to make due to the fact that all autosomes are telocentric, the only element which can be taken into consideration being the relative length. Differences between chromosomes are very small constituting a decreasing serie.

The means of relative lengths (table I) of each chromosome in the two sexes of one species are very close. The values of the standard error of the mean, computed for each chromosome indicate homogenous variants, with the exception of chromosome $r$. This is likewise noticed in the Sheep idiogram in the first three large metacentric chromosomes (BRUERE and MCLAREN, I967), as well as in the Mouse idiogram (LEVAN et al., r962). Another observation recorded in the Mouse idiogram (by the same authors) is that differences of length between the membres of each pair of chromosomes are greatest in pair I, in all our three idiograms this fact is also pointed out (table 2).

Due to the fact that all the autosomes of these two species and of their hybrid are telocentric and therefore the idiogram is made up solely on the basis of the relative length, a division into groups according to the Denver model would be altogether arbitrary.

Applying the variance analysis to parental species (Bos grunniens and Bos taurus), it results that there are no significant differences between the idiograms of the two species taken as a whole $(\mathrm{P}<0,055)$, but that there are very significant differences between different groups of chromosomes from the two species $(\mathrm{P}<0,00 \mathrm{I})$ and the interaction species-chromosome is very significant $(\mathrm{P}<0,00 \mathrm{I})$. Though the idiograms of these two species are similar, there is nevertheless the possibility of differentiating them. 


\section{TABLE I}

Mean values of relative lengths of chromosomes of the haploid set in B. grunniens, B. taurus and their hybrids, expressed as a thousandth times of the total chromosome length (T.C.L.)

\section{TABLEAU I}

Valeurs moyennes des longueurs relatives des chromosomes de la garniture haplö̈de chez B. grunniens, B. taurus et leur hybride, exprimées en millièmes de la longueur chromosomique totale

\begin{tabular}{|c|c|c|c|c|c|c|c|c|c|c|c|c|}
\hline \multirow{2}{*}{$\begin{array}{l}\mathrm{Nr} . \\
\text { chr. }\end{array}$} & \multicolumn{4}{|c|}{ Bos grunniens } & \multicolumn{4}{|c|}{ Bos taurus } & \multicolumn{4}{|c|}{ Hybrids } \\
\hline & $\overline{\mathbf{x}} \lesssim \widehat{ }$ & $\overline{\mathbf{x}} q q$ & $\begin{array}{r}\overline{\mathbf{X}} 30 \\
+\$ 9\end{array}$ & $\mathrm{E}_{\overline{\mathbf{x}}}$ & $\overline{\mathbf{x}}$ & $\overline{\mathbf{X}}_{q q}$ & 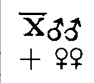 & $E_{\bar{x}}$ & $\overline{\mathbf{x}} \precsim \sigma ゙$ & $\overline{\mathbf{X}} q q$ & 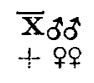 & $\mathrm{E}_{\overline{\mathbf{x}}}$ \\
\hline I & 56,68 & $5^{8}, 43$ & 57,56 & 1,20 & 55,60 & 54,69 & 55, I 5 & 0,97 & $5^{6,30}$ & 55,03 & 55,45 & 0,88 \\
\hline 2 & $5 I, 66$ & 52,62 & 52,15 & $0,5^{8}$ & 46,96 & 47,92 & 47,44 & 0,33 & $5^{\circ}, 66$ & $5^{0,43}$ & $50,5 \mathrm{I}$ & 0,68 \\
\hline 3 & 49,30 & $48,2 \mathrm{I}$ & $4^{8}, 7^{6}$ & $0,5^{8}$ & 45,38 & 45,75 & 45,56 & 0,29 & 47,45 & 47,59 & 47,54 & 0,45 \\
\hline 4 & 47,20 & 45,43 & 46,32 & 0,54 & 44,33 & 43,56 & 43,95 & 0,44 & 45,22 & 45,35 & $45,3 \mathrm{I}$ & 0,28 \\
\hline 5 & 45,88 & 43,63 & 44,75 & 0,67 & $4^{2}, 95$ & $4^{2}, 5^{2}$ & $4^{2}, 73$ & 0,44 & 44,10 & 43,93 & 43,98 & 0,33 \\
\hline 6 & 43,56 & $4^{2}, 75$ & 43,16 & 0,54 & 42,12 & $4^{1} \mathrm{I}, 24$ & $4 \mathrm{I}, 69$ & 0,49 & 43,20 & $4^{2}, 77$ & $4^{2}, 9 \mathrm{I}$ & 0,35 \\
\hline 7 & 42,29 & $4 \mathrm{I}, 86$ & 42,07 & $0,5^{2}$ & $4^{1}, 23$ & $40,5^{2}$ & 40,87 & 0,39 & 42,21 & 41,78 & $4^{I}, 93$ & 0,30 \\
\hline 8 & $40,7 \mathrm{I}$ & $4^{0}, 5^{2}$ & 40,61 & 0,43 & 39,91 & 39,90 & 39,90 & 0,36 & $4 \mathrm{I}, 05$ & 40,94 & 40,98 & 0,34 \\
\hline 9 & $39,8_{4}$ & 39,02 & 39,43 & 0,30 & 38,25 & $3^{8}, 70$ & $3^{8}, 4^{8}$ & 0,33 & 39,16 & 39,53 & $39,4^{\mathrm{I}}$ & 0,26 \\
\hline 10 & 38,63 & 37,57 & 38,09 & 0,35 & 36,39 & 37,32 & 36,85 & 0,38 & 37,64 & 38,28 & 38,07 & 0,35 \\
\hline I I & 37,82 & 36,98 & 37,39 & 0,29 & 35,26 & 35,76 & $35,5 \mathrm{I}$ & 0,33 & 36,98 & $37, \mathrm{II}$ & 37,06 & 0,28 \\
\hline 12 & 36,30 & 36,08 & 36,19 & 0,27 & 34,15 & 34,26 & 34,2 I & 0,29 & 35,65 & 35,82 & 35,78 & 0,24 \\
\hline 13 & 34,54 & 34,69 & 34,62 & 0,30 & 33,13 & 33,01 & 33,07 & 0,28 & 33,69 & 35,62 & 34,98 & 0,26 \\
\hline I 4 & 33,34 & 33,49 & $33,4 \mathrm{I}$ & 0,66 & 31,96 & 31,63 & $3^{1}, 79$ & 0,23 & $3^{2}, 33$ & 32,65 & $3^{2}, 54$ & 0,30 \\
\hline 15 & 31,42 & 32,63 & 32,02 & 0,37 & 30,99 & 30,60 & 30,80 & 0,24 & $30,8 \mathrm{I}$ & $3 \mathrm{I}, \mathrm{I} 3$ & 31,03 & 0,26 \\
\hline 16 & 29,68 & $3 \mathrm{I}, 5 \mathrm{I}$ & 30,59 & 0,39 & 29,95 & 29,74 & 29,84 & $0,3 \mathrm{I}$ & 29,75 & 29,76 & 29,75 & 0,29 \\
\hline 17 & 28,45 & 29,44 & 28,94 & 0,38 & 29,28 & 29, or & 29,14 & 0,32 & 28,45 & 28,34 & 28,37 & 0,30 \\
\hline 18 & 26,56 & $28,0 \mathrm{I}$ & 27,28 & 0,28 & 28,50 & 28,43 & 28,46 & 0,26 & 27,56 & 27,53 & 27,54 & 0,33 \\
\hline 19 & 25,42 & 25,82 & 25,62 & 0,30 & 27,91 & 27,94 & 27,92 & 0,25 & 26,87 & 26,97 & 26,93 & 0,29 \\
\hline 20 & 24,24 & 24,78 & $24,5 \mathrm{I}$ & 0,30 & 27,19 & 27,01 & 27,10 & 0,29 & 26,29 & 26,19 & 26,22 & 0,20 \\
\hline 21 & 23,49 & 24,29 & 23,89 & 0,34 & 26,19 & 26,18 & 26,19 & 0,25 & 25,36 & $25,4 \mathrm{I}$ & $25,4^{\circ}$ & 0,23 \\
\hline 22 & $22,4^{\circ}$ & 23,34 & 22,86 & 0,35 & 25,38 & 25,37 & 25,37 & 0,26 & 24,26 & 24,73 & 24,57 & 0,25 \\
\hline 23 & 21,55 & 22,38 & 21,96 & 0,36 & 24,22 & 24,69 & 24,45 & $0,4^{\circ}$ & 22,83 & 23,78 & 23,46 & 0,33 \\
\hline 24 & $20,7^{\circ}$ & 21,33 & 21,01 & 0,35 & 23,20 & $23,7^{2}$ & 23,46 & 0,30 & 22,17 & 22,42 & 22,33 & 0,28 \\
\hline 25 & $19,7^{\circ}$ & 20,47 & 20,09 & 0,33 & 22,10 & 22,90 & 22,50 & 0,29 & 21,28 & 21,40 & 21,36 & $0,3 x$ \\
\hline 26 & 18,93 & 18,62 & 19,27 & 0,33 & 20,98 & 22,27 & 21,62 & 0,47 & 20,00 & 20,26 & 20,17 & 0,26 \\
\hline 27 & 18,13 & I 8,79 & I 8,46 & 0,42 & 20,29 & 21,19 & 20,74 & 0,46 & $18,6 \mathrm{I}$ & I9, 38 & I9, I 2 & 0,27 \\
\hline 28 & 7,54 & I 7,79 & 17,66 & 0,38 & 18,76 & 19,67 & 19,22 & 0,55 & 17,18 & 17,74 & I 7,55 & 0,28 \\
\hline 29 & I 5,92 & 16,50 & 16,21 & 0,46 & 16,64 & I 7,16 & 16,90 & 0,31 & 14,52 & 16,04 & I 5,33 & 0,52 \\
\hline
\end{tabular}

Representing graphically the relative mean lengths of each chromosome of the haploid set from Bos grunniens $\sigma^{\star}$, Bos taurus $q$ and hybrids ( $\sigma$ and $q$ ), we notice that chromosomes I-I6 are larger in Bos grunniens than in Bos taurus, while from chromosome 16 to 26 the situation is reversed (fig. I). The idiogram line of hybrids has, with a few exceptions, intermediate position as against those of parental species. The crossing place of the parental idiograms, chromosome 16 , is common to that of hybrids. For studying the possible differences between the chromosomes of each of the studied species, and thus the possibility of substituting one chromosome with another, adjacent one, we applied the Tukey test. 
TABLE 2

Mean values of length differences between the chromosomes of each pair, in parental species and hybrids

TABLEAU 2

Valeur moyenne de la longueur des différences entre les chromosomes de chaque paire, dans les espèces parentales et chez l'hybride

\begin{tabular}{|c|c|c|c|}
\hline $\begin{array}{c}\text { Chromosome } \\
\text { pair No. }\end{array}$ & $\begin{array}{c}\text { Bos } \\
\text { grunniens }\end{array}$ & $\begin{array}{l}\text { Bos } \\
\text { taurus }\end{array}$ & Hybrids \\
\hline I & 0,90 & 0,53 & $\mathrm{I}, \mathrm{OI}$ \\
\hline 2 & 0,68 & 0,39 & 0,67 \\
\hline 3 & 0,34 & 0,12 & $0,5 \mathrm{I}$ \\
\hline 4 & 0,39 & 0,14 & 0,58 \\
\hline 5 & 0,2 I & 0,17 & 0,28 \\
\hline 6 & 0,20 & 0,10 & 0,22 \\
\hline 7 & 0,16 & 0,13 & $0, \mathbf{1} 8$ \\
\hline 8 & 0,23 & $0, \mathbf{I}$ I & 0,27 \\
\hline 9 & 0,15 & 0,20 & $0,3^{\circ}$ \\
\hline Io & 0,08 & 0,20 & 0,27 \\
\hline I I & O, I I & $0,2 \mathrm{I}$ & 0,37 \\
\hline I 2 & 0,19 & $0, I_{5}$ & $0,3^{2}$ \\
\hline I3 & 0,14 & 0,09 & 0,35 \\
\hline 14 & 0,13 & 0,16 & 0,44 \\
\hline I5 & 0,19 & 0,15 & 0,27 \\
\hline I6 & 0,26 & 0,05 & 0,30 \\
\hline I7 & 0,20 & 0,09 & 0,25 \\
\hline I 8 & 0,14 & 0,05 & $0,2 \mathrm{I}$ \\
\hline 19 & 0,12 & 0,09 & 0,18 \\
\hline 20 & 0,17 & 0,12 & 0,15 \\
\hline $2 \mathrm{I}$ & 0,08 & 0,04 & 0,14 \\
\hline 22 & 0, I I & 0,12 & $0,2 \mathrm{I}$ \\
\hline 23 & 0,12 & 0,06 & 0,17 \\
\hline 24 & $0,2 \mathrm{I}$ & 0,08 & 0,25 \\
\hline 25 & $0, \mathbf{I} \mathbf{I}$ & 0,06 & 0,20 \\
\hline 26 & 0,12 & 0,06 & 0,12 \\
\hline 27 & 0,09 & 0,13 & 0,32 \\
\hline 28 & 0,15 & 0,18 & 0,42 \\
\hline 29 & 0,08 & 0,13 & $0,5 \mathrm{I}$ \\
\hline
\end{tabular}

The $\mathrm{W}$ calculation was made on the relative length means of each chromosome of the haploid set. In Bos grunniens (fig. 2) there are no significant differences between 2 or 3 adjacent chromosomes. In Bos taurus (fig. 3) the number of adjacent chromosomes between which there are no significant differences is greater than in Yak, comprising generally 5 or 6 chromosomes. In hybrids (fig. 4) the limits are much smaller than in both parental species. In each species and in hybrids there are one or several of the large chromosomes which are significantly different from all the other chromosomes of the set; in Bos grunniens chromosomes $I$ and 2 , in Bos taurus chromosome $I$, and in hybrids the first three large chromosomes. The designation of their position within the idiogram seems certain. 


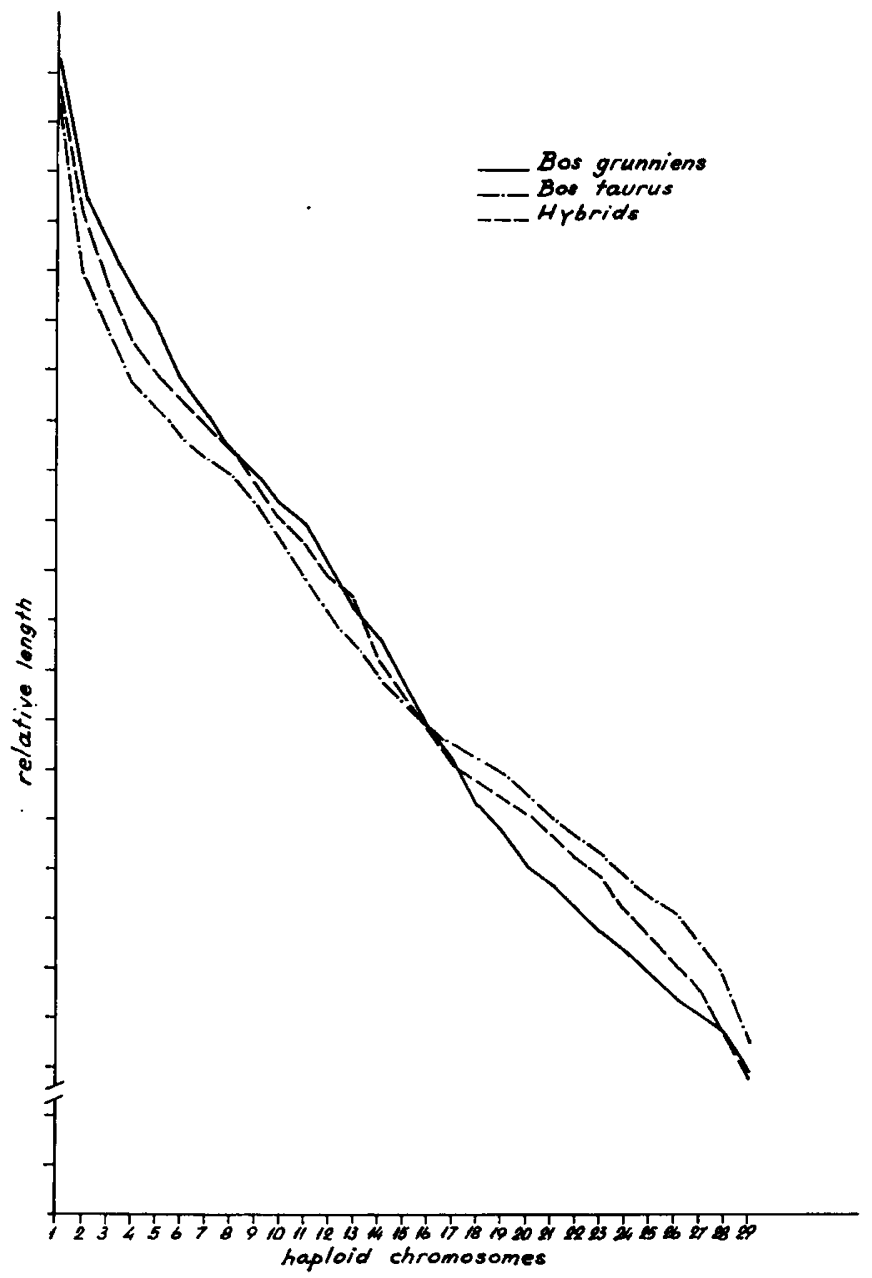

FIG. I. - Graphic representation of relative length of the means of chromosomes (haploid set) in B. taurus, B. grunniens and their hybrids.

FIG. I. - Représentation graphique de la longueur moyenne relative des chromosomes (garniture haploide) chez B. taurus, B. grunniens et leur hybride.

Sexual chromosomes are easily identifiable in Bos grunniens and Bos taurus, being the only metacentric of the set. As in other species of the Bos genus (MELAN DER, I959; BASRUR and MOON, I967), in these two species, Y chromosome is one of the smallest chromosomes of the set. It is submetacentric, with the centromeric index varying between 0,38 and 0,40 (table 3 ). The standard error of $Y$ chromosome mean in hybrids, cattle and particularly in Yak has much higher values than in their autosomes. A predisposition of $\mathrm{Y}$ chromosome to a more accentuated variability of its length as against other chromosomes, explained by the special position of this odd chromosomes, in the process of meiotic division, has been recorded both in man and mouse (LEVAN et al., I962). 

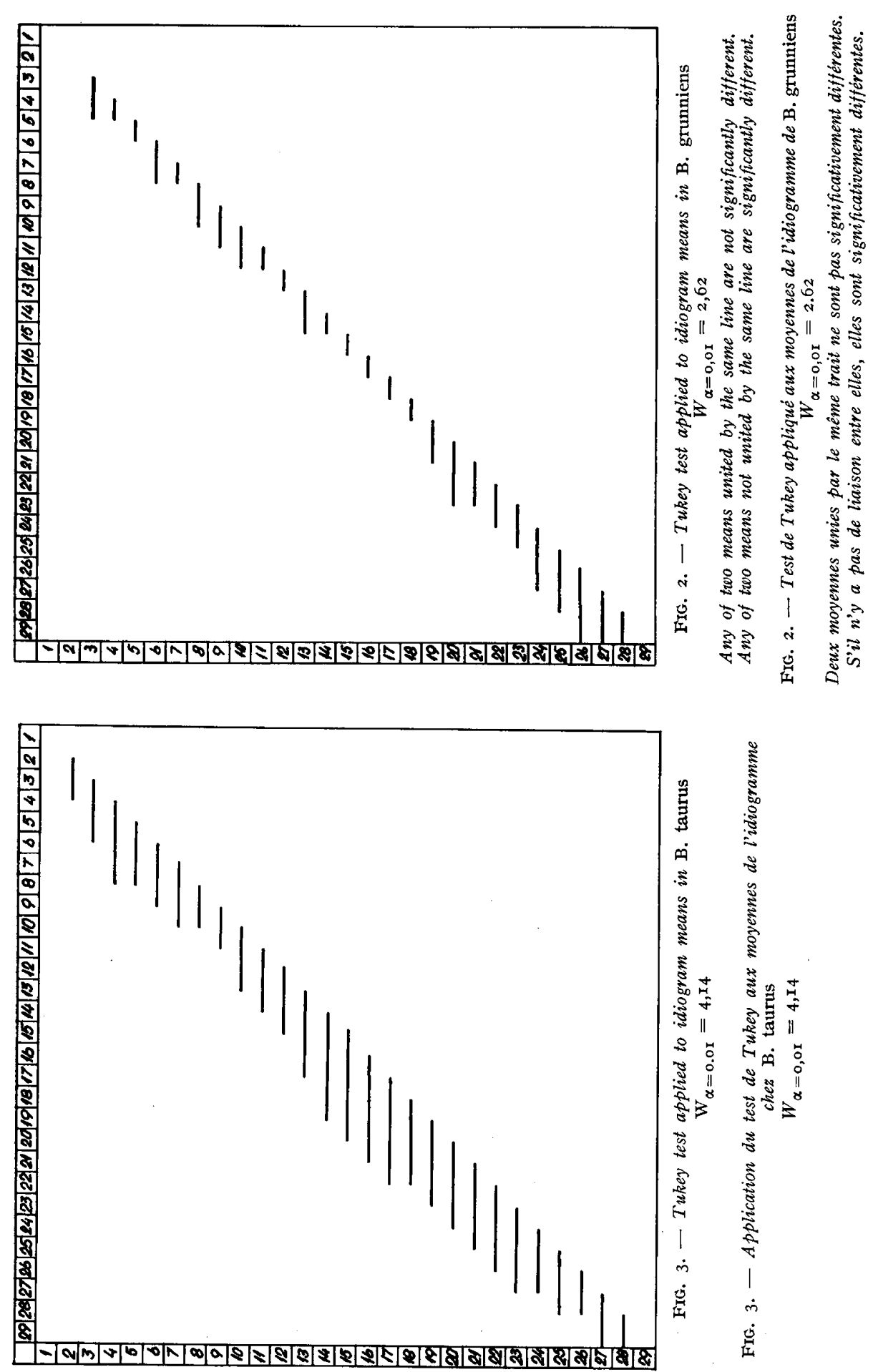


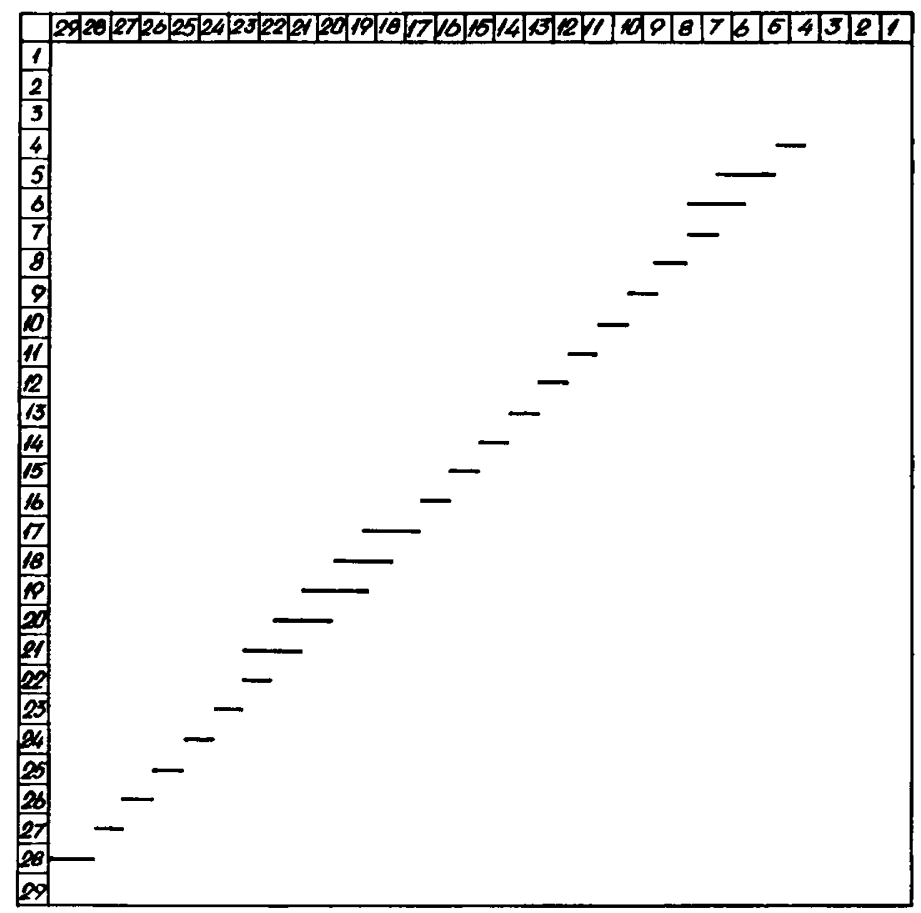

FIG. 4. - Tukey test applied to idiogram means in hybrids $W_{\alpha=0,01}=2,06$

FIG. 4. - Test de Tukey appliqué aux moyennes de l'idiogramme de l'hybride. $W_{\alpha=0,01}=2,06$

In the studied species, just as $\mathrm{Y}$ chromosome, $\mathrm{X}$ chromosome presents nonhomogenous variants, expressed by high values of the standard error of the mean (table 3).

The two $\mathrm{X}$ chromosomes of the females of Bos taurus and hybrids have different dimensions. In Bos taurus the difference is significant $(P<0,05)$, while in hybrids the difference is very significant $(P<0,00 I)$. Between the two $X$ chromosomes of the Bos grunniens female there are no significant differences though they have no identical dimensions. This inequality in females of the two $\mathrm{X}$ chromosomes can be explained as a manifestation of the heteropyknotic condition.

In males $\mathrm{X}$ chromosomes likewise presents non-homogenous variants, particularly in Bos grunniens and hybrids. In Bos taurus the mean standard error is smaller than in yak and hybrids, but greater than in most autosomes.

$\mathrm{X}$ chromosomes are very significantly different in hybrid females $(\mathrm{P}<0,0 \mathrm{I})$. In comparing, by variance analysis, the mean values of the largest among them and mean of the largest from Bos taurus, no significant differences are recorded. 


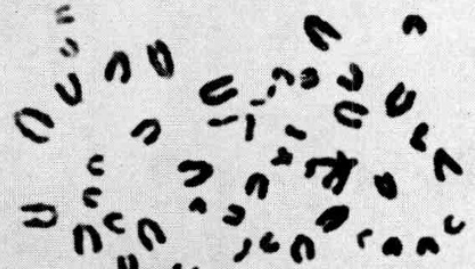

$$
\begin{aligned}
& \text { " } " \text { " }
\end{aligned}
$$
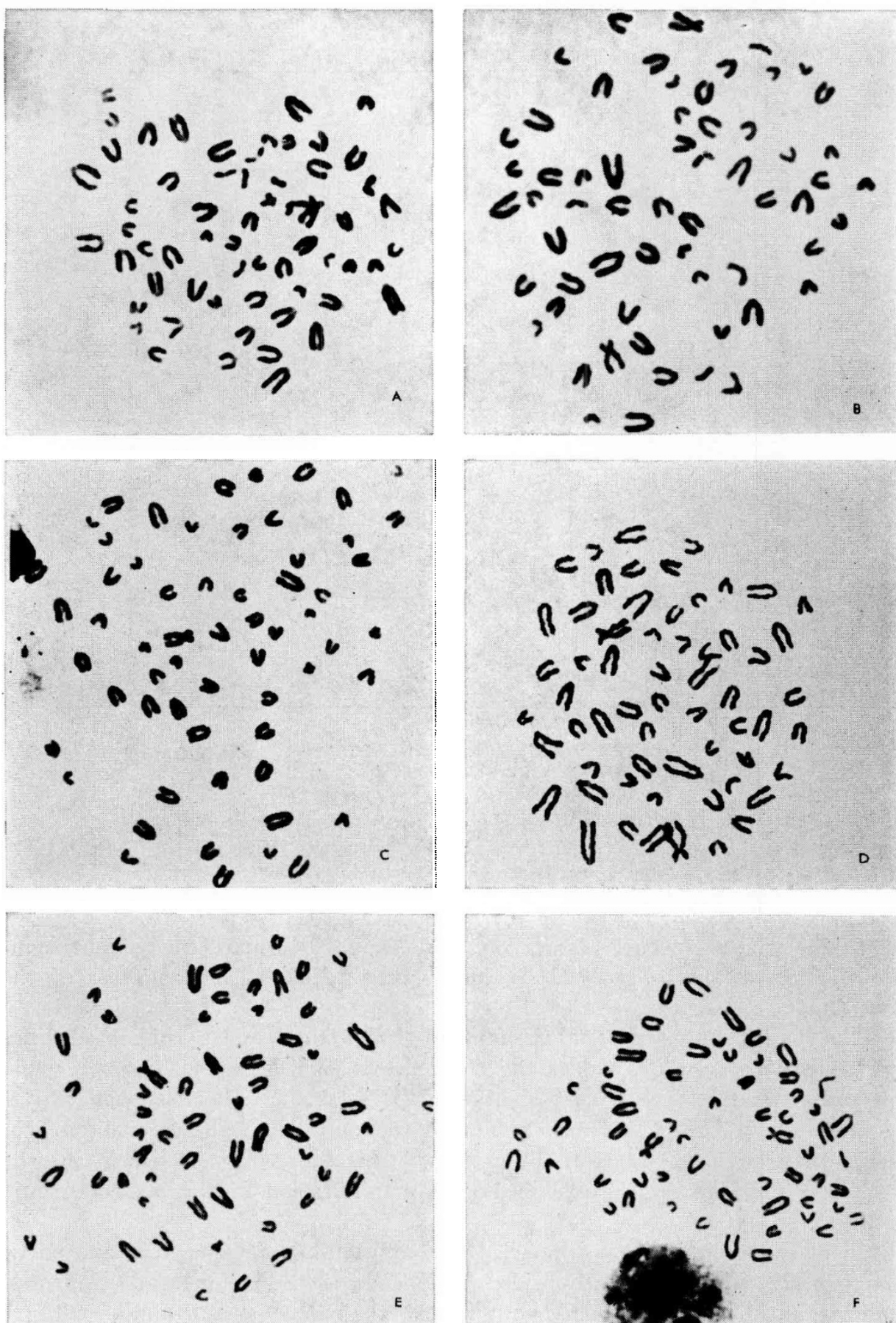

FIG. 5. - Metaphasic chromosomes
A : male Yak
B : female Yak
C : male Cattle
$D$ : female Cattle
E : male hybrid
F : female hybrid

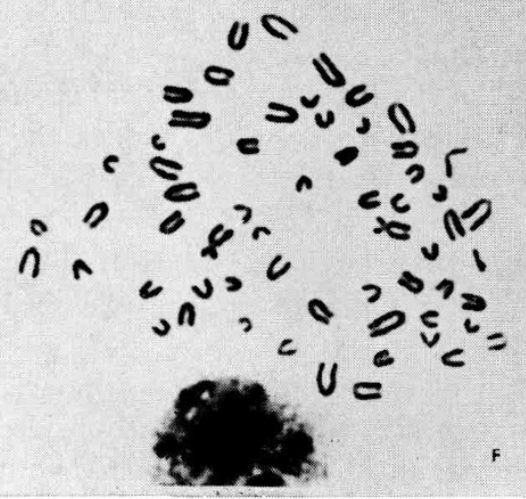

FIG. 5. - Chromosomes mètaphasiques
A : Yak mâle
B : Yak femelle
C : Bœuf mâle
D : Bceuf femelle
E : hybride mâle $F$ : hybride femelle 


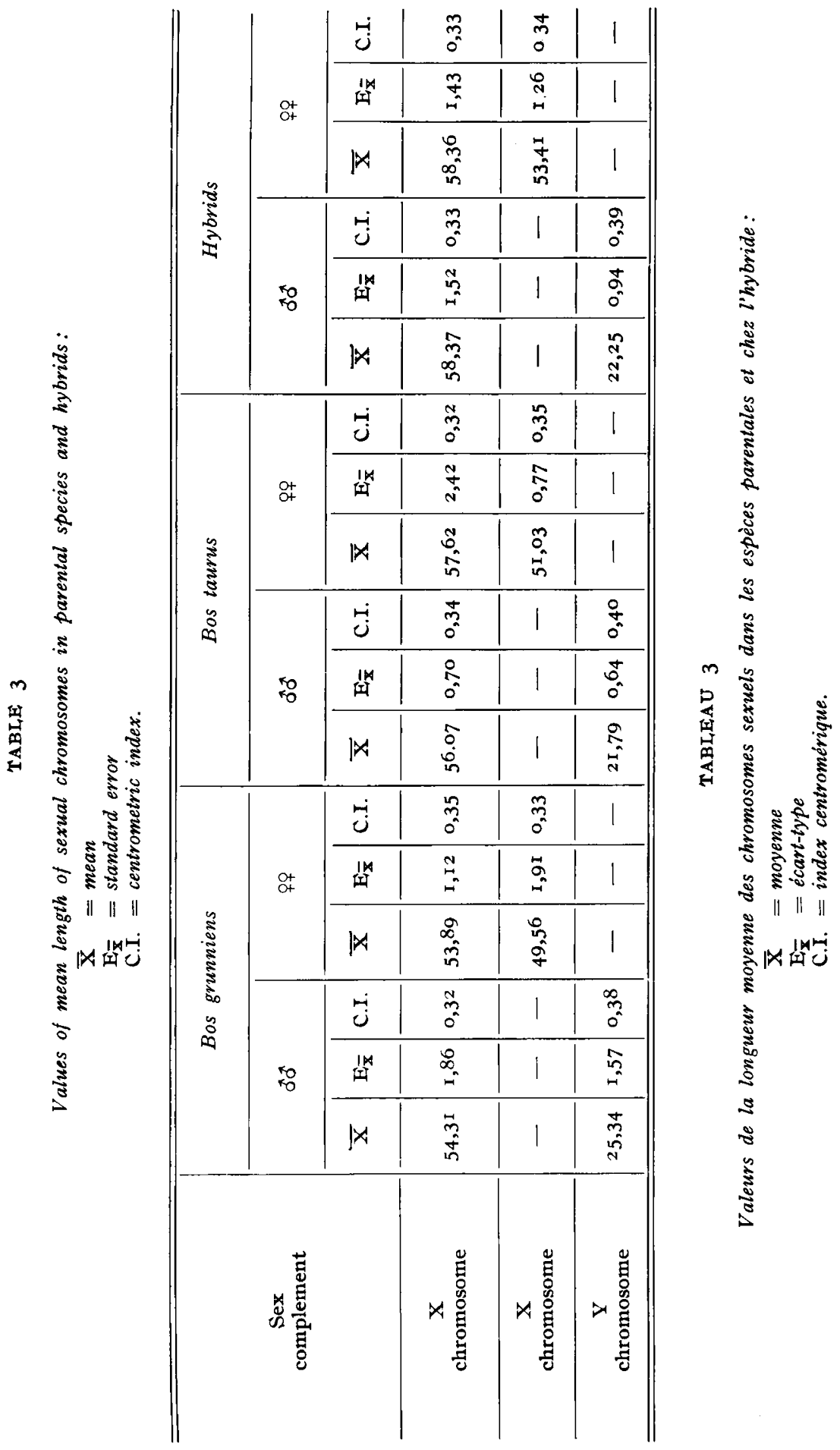


There are, likewise, no significant differences between the smallest Yak X chromosomes and the smallest $\mathrm{X}$ from hybrids, there are, however, significant differences $(\mathrm{P}<0,05)$ between the smallest Bos taurus $\mathrm{X}$ chromosome and the smallest $\mathrm{X}$ from hybrids. It may therefore be assumed, with some probability, that the largest $\mathrm{X}$ chromosome from the hybrid female comes from Bos taurus, while the smallest $\mathrm{X}$ chromosome from Bos grunniens.

In the case of large differences between the karyotypes of two species, the sterility of male hybrids of the first generation is easily explainable. Likewise even, when autosomes are similar but sexual chromosomes and particularly the $X$ chromosome is different, the sterility of hybrid males is ascertained.

In the species studied by us, karyotypes have the same number of chromosomes and both sexual autosomes and chromosomes have a similar morphology. It is posible that, as was also shown by other authors BASRUR and MooN, I967, the infertility of Bos grunniens $\times$ Bos taurus hybrids be induced by a non-equivalence of the homologous segments of sexual chromosomes and by a genic diversity in the heterozygous sex of these species.

Rę̧u pour publication en octobre 1969.

\author{
RÉSUMÉ \\ IDIOGRAMMES DU YAK (BOS GRUNNIENS L.), DU BCEUF (BOS TAURUS L.) \\ ET DE LEUR HYBRIDE
}

Dans le caryotype de ces espèces tous les autosomes sont télocentriques et l'on peut seulement se baser sur la longueur relative des éléments pour établir leur idiogramme. Les chromosomes sexuels sont, quant à eux, aisément identifiables, étant les seuls métacentriques de la garniture.

Les idiogrammes sont très semblables dans les deux expèces, on relève cependant des différences à la fois dans la longueur des autosomes et dans celle des chromosomes sexuels. Les chromosomes 1 à 16 sont plus longs chez Bos grunniens que chez Bos taurus alors que c'est l'inverse pour les chromosomes 16 à 26 . L'idiogramme des hybrides présente un aspect intermédiaire entre celui des 2 espèces parentales.

En dépit des similitudes des caryotypes et des idiogrammes des deux espèces parentales si l'hybride femelle est fertile, le mâle, par contre ne l'est pas. Cette stérilité des mâles pourrait provenir à la fois d'une non-équivalence spécifique des segments homologues des chromosomes sexuels $X$ et $Y$ et de différences dans les gènes portés par le chromosome $Y$ des deux espèces.

\title{
SUMMARY
}

Due to the fact that all autosomes in the caryotypes of these species are teolcentric, the only element which may be considered to work out the idiograms is the relative length of chromosome. The sexual chromosomes are easily identifiable in these species, being the only metacentric ones in the set.

Although the idiograms of these species are similar, there are differences both in the autosomes and in sexual chromosome length. The chromosomes 1-16 are larger in Bos grunniens than in Bos taurus, while the situation is reversed in chromosomes 16-26. The idiogram of hybrids has an intermediate position as against those of the parental species.

In spite of similarities in the caryotypes and idiograms i $f$ the two parental species, the female hybrid is fertile while the male is sterile. This male sterility may be due both to a specific nonequivalence of the homologous segments of the sex chromosomes $X$ and $Y$ and to differences in the genes on the $\mathrm{Y}$ chromosomes of the two species. 


\section{REFERENCES}

BASRUR P. K. and Moon Y. S., r967. Chromosomes of Cattle, Bison and their hybrid, the Cattalo. Amer. J. veter. Res., 28, I319-1 325 .

BruERe A. N. and MCMAREN R. D., 1967. The idiogram of the Sheep with particular reference to secondary constrictions. Canad. J. Genet. Cytol., 9, 543-553.

Derlogea Veturia, Hustiu C., Popescu C., Popescu P. C., I967. Unele particularitati ale hibrizilor Bos grunniens $\times$ Bos taurus. Lucr. sti. Inst. Cerc. Zootech., 25, 183-198.

Derlogea Veturia, Popescu P. C., Grancru I., I967. Cercetari asupra cromozomilor la Yak (Bos grunniens L.) Stud. Cerc. Biol., 19, 267-27r.

Levan A., Hsu T. C. and Stich H. F., I962. The idiogram of the Mouse. Hereditas, 48, 677-687.

I.AY D. M. and Nadler C. F., r969. Hybridization in the rodent genus Meriones. I. Breeding and cytological analysis of Meriones Shawi (ㅇ) $\times$ Meriones libyens ( $\left.{ }^{2}\right)$ hybrids. Cytogenetics, 8, 35-50.

Makino S., Sofuni T., and SASaki M. S., r963. A revised study of the chromosomes in the Horse, the Ass and the Mule. Proc. Jap. Acad., 39, 176-181.

Melander Y., I959. The mitotic chromosomes of some cavicorn Mammals, Bos taurus L., Bison bonasus $L$. , and Ovis aries $L$. Hereditas, 45, 649-664.

Nichols W. W., Levan A. and LAWRence W. C., 1962. Bovine chromosomes by the peripheral blood method. Hereditas, 48, 536-538.

Zuitin A. I., r935. On the chromosomes of the Yak (Phoephagus grunniens L.). Dokl. Akad. Nauk Uz. SSR, 4, 8I-83.

Zurrin A. I., 1938. New data on the chromosome number in Yak (Phoephagus grunniens L.). Dokl. Akad. Nauk Uz. SSR, 19, 201-202. 